\title{
STABILITY ANALYSES FOR INTERPRETING GENOTYPE BY ENVIRONMENT INTERACTION OF SELECTED ORIENTAL TOBACCO LANDRACES
}

\author{
Dursun KURT \\ Ondokuz Mayls University, Vocational School of Bafra, Department of Plant and Animal Production, \\ Samsun, TURKEY \\ Corresponding author: dursunkurtt@gmail.com
}

Received: 16.01.2020.

\begin{abstract}
Advanced pure lines, which are in different genetic and vegetative characteristics determined in a breeding program initiated in 2013, were included to the yield tests in the region before registration. Chemical and morphological variability and stability of 13 advanced pure tobacco lines and 2 standard varieties were determined in two different locations. The experimental layout was random blocks with three replications and the experiment was carried out in 2016 and 2017. Plant height values ranged from 85.25 to $156.71 \mathrm{~cm}$, the

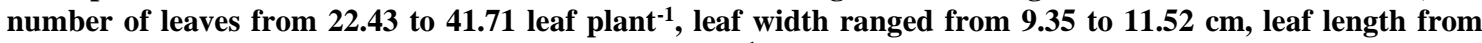
17.36 to $21.89 \mathrm{~cm}$, yield from 1371.9 to $1756.7 \mathrm{~kg} \mathrm{ha}^{-1}$, quality grade index from 67.33 to $81.58 \%$, nicotine content from 1.02 to $1.98 \%$ and glucose content from 3.33 to $9.33 \%$. The lines $16,21,26$ and 45 were identified as strong variety candidates suitable for the region based on all the parameters and the statistical conditions examined. The use of biplots that the environments were distributed on axes, enabled to make location-based variety recommendations. The biplot graph based on environment and genotype interaction was used in the recommedations of tobacco variety for each location.
\end{abstract}

Keywords: Chemical contents, HPLC, Samsun type, quality, yield

\section{INTRODUCTION}

Tobacco (Nicotiana tabacum L.) is the feedstock of cigarette industry, which differs from other cultivated plants with the alkaloid accumulation in the leaves, that is synthesized in the root tissues. The highest quality tobacco in the world is grown in Turkey with the contribution of the suitability of ecological factors and long term specific experience of cultivation technique. Tobacco, despite declining production in Turkey, is an indispensable source of livelihood of small family farms in rural areas. Sustainable alternative to tobacco has not been identified. The sharp decrease in production has been recently associated with a decrease in the number of producers, an increase in the average age of the producers, the difficulty of tobacco cultivation, price policies and anti-smoking campaigns (Ekren and Ilker, 2017). The production of tobacco in the same area every year and the use of poor quality seeds were also reported the possible causes of decrease in tobacco production (Celen et al., 2016).

The physical and chemical properties of tobacco are determined by the genetic structure, agricultural practices, soil structure and fertilization, climate, dissease and pest condition, hand group, harvesting and curing conditions (Leffingwell, 2001). The deviation of a tobacco variety from the maximum quality of genetic potential may be related to various impacts of environmental factors. Environmental impacts stimulate plants to maintain the quality grade index with biochemical and morphological mechanisms, which bring out the quality qualifications that distinguish oriental tobacco from others tobacco types (Senbayram et al., 2005).

Commercial cigarette blends are the non-irritating taste of different tobacco types and classes, and balanced blends to the enjoyment of smokers (Wu et al., 1992). Each tobacco type has specific roles such as reducing/increasing the nicotine content in the blend added, regulating total sugar, regulating the speed/satiety of smoking, transferring its own aromatic structure or improving the color composition. The most effective treatment to chemical and physical quality is curing. In the flue cured method, where curing is completed in as short as 5 days, gradually increasing temperatures prevent oxidations and enzyme activities leading to red-dark colors and the color of the curing product turns into yellow. The long curing period in the air cured method (Burley) leads continuation of hydrolytic and oxidative process till the last stage, and the darkness of color increases. The climate factor stands out in the sun cured 
method. The long curing period in the black Sea region where the relative humidity is high causes color towards red in dark tones and the moderate sugar content. While short-term curing under dry and high temperatures in the Aegean region leads to the formation of products with high sugar content and dominated by yellow tints (Aksu and Elmas, 1993; Odabasoglu, 1994; Yazan and Gencer, 2001).

The main goal of the breeder is to develop varieties with wide adaptability, high yield and quality, however, this process becomes much more complicated by the influence of genotype $\mathrm{x}$ environment interactions (Erdemci, 2018), and the selection of superior genotypes becomes difficult (Mohammadi et al., 2012). The terms "stability" and "adaptability" are used for genotypes showing consistent performance in variable environments (Romagosa and Fox, 1993). Explaining the performance of genotypes in different environments is difficult with a single statistical method (Dehghani et al., 2006). In addition to classical methods, different stability analyzes such as multivariate analysis (Westcoff, 1987), cluster analysis (Crossa et al., 1991), regression analysis (Gauch, 1988), additive main effects and multiplicative interaction model (Gauch, 1992) are used to explain the genotype $x$ environment interaction. The most powerful and optimal technique recently used is the genotype $\mathrm{x}$ environment biplot technique owing to providing a visual presentation of the interactions (Yan et al., 2001; Dehghani et al., 2006; Mumtaz et al., 2019). Tobacco selection in the natural population do not allow to obtain a new genotype, only an existing individual is highlighted. Moreover, mutation is common in tobacco due to the amphidiploid origin, therefore, selection should be continued to maintain the characteristics of a line highlighted (Usturali et al., 1998).

Tobaccos having different genetic structure exhibit a wide variation in physical and chemical quality characteristics. The ever-increasing variation in physical and chemical quality characteristics is very important for plant breeding (Zeba and Isbat, 2011). However this causes significant reductions in the quality of the regional tobacco and is controlled by the producers (Acquaah, 2007). Seedling production, field stage, harvest time, curing time and curing tecnique of different genotypes are different from each other. When tobacco types with different characteristics are produced together, some types mature early, others late, and a product at undesired homogeneity and quality is obtained at the end of the curing. The pure lines with the characteristics desired by the tobacco producer and industry were identified in the study started in 2013, and 13 advanced lines were selected following a series of laboratories and field studies. In this study, 13 advanced tobacco lines and 2 standard varieties were included into the experiments conducted in two different locations. The stability-based genotype $\mathrm{x}$ environment interactions were examined and the most stable genotype/genotypes were determined.

\section{MATERIALS AND METHODS}

\section{Plant materials}

The landraces used in the study were collected from the Samsun province of Turkey (Table 1) where tobacco production was intensive in 2013 according to the morphological features (number of leaves, leaf color, leaf size and leaf texture etc.). At the beginning of flowering, flowers were isolated by inserting bags. 58 genotypes collected along with maturation of the seeds were subjected to DNA Fingerprint analysis in early 2014 and their affinities were determined. After these analyzes, 48 lines, which are found to be different in terms of genetic structure, and 2 standards (Nail and Canik 190-5) in 2014 and 2015, were included in the field researchs of Gökçekent villages of Bafra district. In the present study, it was investigated the chemical and morphological variability and stability among 2 standarts (Nail and Canik 190-5) with 13 superior landraces (were selected in previous researches) in 2016-2017 years. These standarts are commonly cultivated in Samsun.

Table 1. Geographical data for the villages where tobacco landraces were collected

\begin{tabular}{|c|c|c|c|c|c|c|c|c|c|}
\hline Code & Village & Altitude & Longitude & Latitude & Code & Village & Altitude & Longitude & Latitude \\
\hline 2 & Balcalı & 47 & $41^{0} 09^{\prime} 16^{\prime \prime}$ & $36^{0} 34^{\prime} 59^{\prime \prime}$ & 21 & Gökçekent & 48 & $41^{0} 32^{\prime} 29^{\prime \prime}$ & $35^{0} 48^{\prime} 10^{\prime \prime}$ \\
\hline 3 & Gökçesu & 146 & $41^{0} 31^{\prime} 16^{\prime \prime}$ & $35^{0} 47^{\prime} 92^{\prime \prime}$ & 23 & Gökçekent & 103 & $41^{0} 32^{\prime} 41^{\prime \prime}$ & $35^{0} 48^{\prime} 52^{\prime \prime}$ \\
\hline 8 & Çinik & 44 & $41^{0} 11^{\prime} 38^{\prime \prime}$ & $36^{0} 28^{\prime} 91^{\prime \prime}$ & 26 & Dedeli & 26 & $41^{0} 32^{\prime} 04^{\prime \prime}$ & $35^{0} 50^{\prime} 20^{\prime \prime}$ \\
\hline 11 & Gökçesu & 158 & $41^{0} 31^{\prime} 17^{\prime \prime}$ & $35^{0} 47^{\prime} 81^{\prime \prime}$ & 29 & Hamzalı & 14 & $41^{0} 12^{\prime} 15^{\prime \prime}$ & $36^{0} 31^{\prime} 45^{\prime \prime}$ \\
\hline 13 & Karabürük & 13 & $41^{0} 12^{\prime} 36^{\prime \prime}$ & $36^{0} 33^{\prime} 54^{\prime \prime}$ & 45 & Balcalı & 54 & $41^{0} 09^{\prime} 07^{\prime \prime}$ & $36^{0} 33^{\prime} 56^{\prime \prime}$ \\
\hline 16 & Gökçesu & 153 & $41^{0} 31^{\prime} 17^{\prime \prime}$ & $35^{0} 47^{\prime} 26^{\prime \prime}$ & 57 & Harız & 22 & $41^{0} 36^{\prime} 37^{\prime \prime}$ & $35^{0} 50^{\prime} 46^{\prime \prime}$ \\
\hline 20 & Balcalı & 51 & $41^{\circ} 08^{\prime} 31^{\prime \prime}$ & $36^{0} 34^{\prime} 05^{\prime \prime}$ & & & & & \\
\hline
\end{tabular}

\section{Field experiments}

This study was conducted out in Çataltepe (Bafra, 41031'22"N, 35045'55'E, altitude $154 \mathrm{~m})$ and Gökçeboğaz (Alaçam, 41³6'32'N, 35³9'08'E, altitude $26 \mathrm{~m}$ ) with 2 standarts and 13 superior lines in accordance with the design of randomized blocks with three replications in 2016 and 2017 years. Seedlings belonging to the genotypes were grown in the peat environment, in the viols, in the float system. Each plot is composed of 4 rows of $5 \mathrm{~m}$ tall, transplanting at distances of $45 \times 10 \mathrm{~cm}$. Between the plots $1 \mathrm{~m}$ and $50 \mathrm{~cm}$ edge effects at the ends of the leaves were left, harvesting operations were completed in 3 times. In the plants that flowered, the plant height, number of leaf, leaf width and length were measured in the main hands (Ekren and Ilker, 2017). Leaves arranged manually were cured in the sun, and 
organoleptic evaluations were analysed according to American Grade System by tobacco technological experts, which called "quality grade index". The cured tobacco was yield measurements were made as fixed to $17 \%$ humidity.

\section{Chromatographic methods for analytes}

Standards, reagents and chemicals were obtained from Sigma and Merck and they are either chromatographic or analytical grade. Millipore ultrapure water (Type I) was used for all analysis. Nicotine and glucose were investigated as chemical contents according to chromatographic conditions, which was optimized by Kinay (2018). Extracts were analyzed with the aid of an HPLC system equipped with DAD detector for nicotine and with RI detector for glucose. The mobile phase consist of $\% 0.1$ acetic acid and acetonitrile $(85: 15, \mathrm{v} / \mathrm{v})$ for nicotine, acetonitrile:water $(75: 25, \mathrm{v}: \mathrm{v})$ for glucose. Samples of nicotine were prepared by weighing approximately $200 \mathrm{mg}$ of tobacco into a $20 \mathrm{ml}$ tubes, adding $18 \mathrm{ml}$ of water (consist \%0.1 acetic acid) and $2 \mathrm{~mL}$ acetonitrile. Samples of glucose were prepared by weighing approximately $1.00 \mathrm{~g}$ of tobacco into a $25 \mathrm{ml}$ tubes, adding $20 \mathrm{~mL}$ of water (consist \%0.1 acetic acid) and $5 \mathrm{~mL}$ methanol. Chemical contents were calculated from resultant chromatograms previously subjected to standard calibrations $\left(\mathrm{r}^{2} ; 0.999\right.$ and 1$)$. Extraction recovery ratios indicating the reliability of analyses were obtained as $101 \%$ for nicotine and $106 \%$ for glucose.

\section{Statistical analysis}

Resultant data were subjected to variance analyses in accordance with randomized block design with SAS program and means were compared with Duncan's multiple range test. Years were considered as different environments. Stability analysis of the genotypes tested were determined according to parameter means (x), regression coefficient (b), regression line intercept (a), determination coefficient $\left(\mathrm{r}^{2}\right)$, coefficient variation $(\mathrm{CV})$ and deviation from regression $\left(\mathrm{S}^{2} \mathrm{~d}\right)$ for the parameters namely, yield, quality grade index, nicotine and glucose. Adaptation groups of genotypes were created according to the parameter means (x), regression coefficients (b), and confidence intervals (Sayar et al., 2013). Biplot was used according to environment-focused scaling for environmental evaluation (ideal and discriminating environments).

\section{RESULTS AND DISCUSSION}

\section{Variations in physical and chemical characteristics}

The variance analysis revealed that the differences in all parameteres investigated were statistically significant $(\mathrm{P}<0.01)$ between the locations, genotypes and their interactions (Table 2). The changes in the environment had a significant impact on the studied characteristics of genotypes. Sadeghi et al., (2011) investigated the yield performances of 15 hybrid tobacco in eight different environments and indicated that $87.89 \%$ of the variability was explained with the environment, $2.36 \%$ with the genotype and the rest with the interaction of genotype $x$ environment effect. The results of Duncan test for all parameters were shown in Table 2.

Agronomic characterization of local varieties should be examined comparing with a cultivar and/or population recognized by the producers of the region. The presence of a line superior to any character from such a variety/population indicates that the population carries important alleles. Plant height, which has a strong-positive relationship with the number of leaf and yield (Aytac, 2016), is the most affected characteristic of oriental tobacco by changing environmental conditions (KorubinAleksoska et al., 2014). The plant height in this study was measured between 85.25 and $156.71 \mathrm{~cm}$ and a variation of approximately $84 \%$ was calculated based on the differences in plant heights. The plant height values of Samsun type tobaccos under similar locations varied from 45 to $142 \mathrm{~cm}$, the number of leaves from 22.20 to 31.40 leaf plant ${ }^{-1}$, leaf width from 5.07 to $14.32 \mathrm{~cm}$, leaf length from 12.39 to $24.02 \mathrm{~cm}$, yield from 824 to $1611 \mathrm{~kg} \mathrm{ha}^{-1}$, quality grade index from 62 to $80 \%$, nicotine content from 0.7 to $2.9 \%$ and reduced sugar content from 2.58 to 10.51\% (Karpat, 1989; Esendal et al., 1997, 2001, 2007; Camas et al., 1997, 2009; Camas, 1998; Caliskan, 2006; Zorba, 2008; Peksuslu et al., 2012; Kinay, 2014; Aytac, 2016; Kurt, 2019). The plant height averages of two standard varieties was behind the landraces averages. The plant heights of 9 out of 13 landraces $(2,8,11,13,20,21$, $23,29,57)$ were longer than two standard varieties. The results of higher number of leaves for 8 lines compared to the two standard varieties is not a coincidence. The line 21 is higher than standard Canik 190-5 variety and at the the same statistical group with the Nail variety. The growth in leaf sizes leads to the decrease in quality, therefore, it is not a desirable characteristic for tobaccos. The leaf sizes measured in the study are compatible with the aforementioned literature. Therefore, the yield increase in oriental tobacco con be achieved by increasing the number of leaves, however the increase in the numbe rof leaves is not sufficient alone. Because the yield of landrace 23, which had the highest number of leaves, was much lower than the many genotypes. Leaf yield in tobacco is directly related to the plant height, leaf number, leaf width and length (Butorac et al., 2004), and leaf width was reported to increase the yield (Dyulgerski \& Dimanov, 2012). The relationships between plant height, leaf number, leaf width and length were shown in Table 2. The mean yield value in the study was $1553.3 \mathrm{~kg} \mathrm{ha}^{-1}$ which was higher that those reported in previous studies. Landraces 21 and 26 stand out with their high yield values.

The ratio of carbohydrates, aromatic substances, nicotine and nitrogenous substances in the chemical structure affects the quality, and ecological factors affect the chemical structure (Bruck et al., 2008). Nicotine is the most abundant alkaloid in tobacco among more than 20 alkaloids and causes widespread use of tobacco products worldwide (Xia et al., 2014). 
Table 2. Agronomic, technological and chemical properties of the tobacco genotypes in different four environments

\begin{tabular}{|c|c|c|c|c|c|c|c|c|}
\hline Genotypes & $\begin{array}{c}\text { Plant } \\
\text { Height }(\mathrm{cm})\end{array}$ & $\begin{array}{l}\text { Number of } \\
\text { Leaves }\end{array}$ & $\begin{array}{c}\text { Leaf } \\
\text { Width } \\
(\mathbf{c m}) \\
\end{array}$ & $\begin{array}{c}\text { Leaf } \\
\text { Lenght } \\
(\mathbf{c m})\end{array}$ & $\begin{array}{c}\text { Yield } \\
\left(\mathrm{kg} \mathrm{ha}^{-1}\right)\end{array}$ & $\begin{array}{c}\text { Quality } \\
\text { Grade } \\
\text { Index (\%) }\end{array}$ & $\begin{array}{l}\text { Nicotine } \\
(\%)\end{array}$ & $\begin{array}{c}\text { Glucose } \\
(\%)\end{array}$ \\
\hline 2 & $128.93 \mathrm{c}$ & $32.02 \mathrm{e}$ & $9.85 \mathrm{~cd}$ & $21.04 \mathrm{bd}$ & $1608.5 \mathrm{~d}$ & $78.08 \mathrm{bc}$ & $1.07 \mathrm{~h}$ & $3.80 \mathrm{hi}$ \\
\hline 3 & $107.70 \mathrm{f}$ & $24.92 \mathrm{~g}$ & $11.38 \mathrm{a}$ & 19.64 ef & $1615.3 \mathrm{~d}$ & $78.58 \mathrm{ac}$ & $1.51 \mathrm{f}$ & $7.84 \mathrm{c}$ \\
\hline 8 & $156.71 \mathrm{a}$ & $40.15 \mathrm{~b}$ & $9.84 \mathrm{~cd}$ & $21.89 \mathrm{a}$ & 1543.0 ef & $67.75 \mathrm{f}$ & $1.02 \mathrm{~h}$ & $3.61 \mathrm{ij}$ \\
\hline 11 & $130.79 \mathrm{c}$ & $27.75 \mathrm{f}$ & $9.37 \mathrm{e}$ & $21.15 \mathrm{ad}$ & $1409.9 \mathrm{i}$ & $67.33 \mathrm{f}$ & $1.04 \mathrm{~h}$ & $3.33 \mathrm{j}$ \\
\hline 13 & $129.59 \mathrm{c}$ & $33.50 \mathrm{~d}$ & $10.10 \mathrm{bd}$ & $20.69 \mathrm{bd}$ & $1495.0 \mathrm{gh}$ & $73.92 \mathrm{e}$ & $1.67 \mathrm{~d}$ & $4.10 \mathrm{~h}$ \\
\hline 16 & $94.99 \mathrm{~g}$ & $22.61 \mathrm{~h}$ & $10.52 \mathrm{~b}$ & $21.26 \mathrm{ac}$ & $1562.5 \mathrm{e}$ & $81.50 \mathrm{a}$ & $1.75 \mathrm{c}$ & $5.11 \mathrm{fg}$ \\
\hline 20 & $138.13 \mathrm{~b}$ & $33.75 \mathrm{~d}$ & $9.72 \mathrm{de}$ & $20.82 \mathrm{bd}$ & $1471.5 \mathrm{~h}$ & 77.17 be & $1.56 \mathrm{f}$ & $4.73 \mathrm{~g}$ \\
\hline 21 & $116.06 \mathrm{de}$ & $25.19 \mathrm{~g}$ & $11.39 \mathrm{a}$ & $20.53 \mathrm{~cd}$ & $1756.7 \mathrm{a}$ & $80.08 \mathrm{ab}$ & $1.51 \mathrm{f}$ & $8.75 \mathrm{~b}$ \\
\hline 23 & $115.26 \mathrm{de}$ & $41.71 \mathrm{a}$ & $9.93 \mathrm{~cd}$ & $17.44 \mathrm{~g}$ & $1513.0 \mathrm{fg}$ & $74.50 \mathrm{de}$ & $1.85 \mathrm{~b}$ & $3.73 \mathrm{hj}$ \\
\hline 26 & $96.76 \mathrm{~g}$ & $23.02 \mathrm{~h}$ & $10.54 \mathrm{~b}$ & $21.53 \mathrm{ab}$ & $1696.7 \mathrm{~b}$ & $81.58 \mathrm{a}$ & $1.61 \mathrm{e}$ & $7.79 \mathrm{c}$ \\
\hline 29 & $117.56 \mathrm{~d}$ & $36.09 \mathrm{c}$ & $9.35 \mathrm{e}$ & $19.32 \mathrm{f}$ & $1371.9 \mathrm{j}$ & $78.33 \mathrm{ac}$ & $1.87 \mathrm{~b}$ & $5.45 \mathrm{f}$ \\
\hline 45 & $93.49 \mathrm{~g}$ & $23.38 \mathrm{~h}$ & $10.24 \mathrm{bc}$ & $20.81 \mathrm{bd}$ & $1653.3 \mathrm{c}$ & $78.75 \mathrm{ab}$ & $1.53 \mathrm{f}$ & $9.33 \mathrm{a}$ \\
\hline 57 & $112.01 \mathrm{ef}$ & $38.96 \mathrm{~b}$ & $9.97 \mathrm{~cd}$ & $17.36 \mathrm{~g}$ & $1395.4 \mathrm{ij}$ & $77.58 \mathrm{bd}$ & $1.62 \mathrm{e}$ & $7.11 \mathrm{~d}$ \\
\hline Nail (std) & $109.93 \mathrm{f}$ & $25.23 \mathrm{~g}$ & $11.52 \mathrm{a}$ & $21.07 \mathrm{ad}$ & $1690.8 \mathrm{~b}$ & $75.25 \mathrm{ce}$ & $1.35 \mathrm{~g}$ & $7.22 \mathrm{~d}$ \\
\hline Canik (std) & $85.25 \mathrm{~h}$ & $22.43 \mathrm{~h}$ & $10.19 \mathrm{bd}$ & $20.35 \mathrm{de}$ & $1515.3 \mathrm{fg}$ & $80.50 \mathrm{ab}$ & $1.98 \mathrm{a}$ & $6.11 \mathrm{e}$ \\
\hline Mean & 115.54 & 30.05 & 10.26 & 20.33 & 1553.3 & 76.73 & 1.53 & 5.87 \\
\hline LSD $_{0.05}$ & 4.99 & 1.40 & 0.41 & 0.75 & 31.3 & 2.96 & 0.05 & 0.43 \\
\hline CV\% & 5.33 & 5.78 & 5.00 & 4.58 & 2.49 & 4.77 & 3.97 & 9.05 \\
\hline \multicolumn{9}{|c|}{ Mean Square and Significance } \\
\hline Location & $6661.22 * *$ & $419.79 * *$ & $4.86 * *$ & $20.36 * *$ & $2741.18 * *$ & $8452.11 * *$ & $6.51 * *$ & $155.02 * *$ \\
\hline Genotype & $115.12 * *$ & $573.19 * *$ & $5.76 * *$ & $25.51 * *$ & $1623.87 * *$ & $230.24 * *$ & $1.06 * *$ & $48.71 * *$ \\
\hline GxL & $153.41 * *$ & $16.06 * *$ & $0.98 * *$ & $3.41 * *$ & $1206.68 * *$ & $98.85 * *$ & $0.64 * *$ & $23.91 * *$ \\
\hline Error & 38.00 & 3.02 & 0.26 & 0.87 & 14.95 & 13.40 & 1.53 & 0.28 \\
\hline
\end{tabular}

*Values followed by different letters in each column are significantly different $(\mathrm{P}<0.05)$ according to Duncan test, std; Standart variety, LSD; Least significant difference, CV; Coefficent of variation, GxL; Genotype x Location

Sugars are known to balance the smoke flavor by altering the sensory effect of tobacco alkaloids. In a typical American blend, 3 to $15 \%$ oriental tobacco is used and the total sugar content of the blend is approximately $12 \%$ of which $8 \%$ comes from natural and $4 \%$ from additional sweeteners. Glucose and fructose are the most important soluble sugars and are called reducing sugars (Roomer et al., 2012). The glucose ratio in oriental tobacco is reported at least 2\% (Ramusino et al., 1994), but studies reporting around $10 \%$ were also encountered (Sekin, 1979). The sugar content of the tobaccos grown in Black Sea region is expected to be always contain less sugar than the Izmir type (Sekin, 1979). The dominance of red color after curing of Samsun tobaccos was ascribed with the excess amount of chemical content in the tissues (Eser, 1994). The researcher indicated that yellow color is formed with a short-term curing due to the excess water in the tobacco grown lowlands. In other words, sugar content decreases under prolonged curing period due to the high relative humidity and low temperatures in curing period (Aksu and Elmas, 1993; Odabasoglu, 1994; Yazan and Gencer, 2001). The quality grade index and nicotine content values obtained in the study are in conformity with the acceptable limits and the reported literature and meet the expectations of the industry.

\section{Genotype x Environment Interactions and Stability Analyses}

Stability is the response of genotypes to environmental conditions. Genotypes are called stable when they are not affected by changes in environmental conditions and unstable when affected (Topal and Yildiz, 2011). The regression coefficient (b) is obtained by ratio of the covariance (measure of co-variation) between the genotype and the environmental indexes to the variance of the environmental indexes. The regression coefficient close to 1.0 indicates an average stability over all environments (Sabanci, 1997), the regression coefficient greater than 1.0 indicates a good environmental-specific adaptation of the genotype, and the regression coefficient less than 1.0 shows a specific adaptation of the genotype to the bad environment (Topal and Yildiz, 2011). The average yield in this study was $1553.3 \mathrm{~kg} \mathrm{ha}^{-1}$. Since high yield is a desirable characteristic, genotypes with higher yield than the general average yield are accepted providing the first condition of the stability. Landraces of 2, 16, 21 and 45 are stable due to higher yield than the 
average yield and the regression coefficient within the confidence interval $(0.72<\mathrm{b}<1.28)$. According to the same criteria, 16, 21 and 45 landraces with respect to quality grade index, 3, 13, 16, 20, 21, 26, 45 landraces for nicotine content and 3, 21, 26 landraces considering glucose contents are stable genotypes (Table 3,4).

The positive regression constant (a) indicates a good performance of genotypes in all environmental conditions (Finlay and Wilkinson, 1963). The determination coefficient $\left(\mathrm{r}^{2}\right)$ expressing the ratio of reflection in the environmental changes of the genotypes to the yield should be high and the deviation from the regression $\left(\mathrm{S}^{2} \mathrm{~d}\right)$ should be close to zero. (Eberhart and Russell, 1966; Teich, 1983). Genotypes with low coefficient of variation (CV) under different environmentals conditions are considered stable (Francis and Kannenberg, 1978). In other words, stable genotype is insensitive to changing environmental conditions (Sabanci, 1997). Landrace 21 is the only genotype providing all aforementioned conditions for all parameters. Landrace 45 provided all the conditions in nicotine content. However, some genotypes that cannot meet one of the conditions are also noteworthy. In this regard, landrace of $16(\mathrm{a} ;-9.11)$ for yield, $16(\mathrm{a} ;-4.84)$ and $20(\mathrm{~b} ; 0.71)$ for quality grade index, $16(-0.07)$ for nicotine, $16(\mathrm{~b} ; 0.49)$ and $26\left(\mathrm{r}^{2} ; 0.86\right)$ for glucose should be evaluated (Table 3, 4). Genotypes with moderate adaptability to all environments according to the adaptation classes are landraces 2 and 16 for the yield, 45 for the quality grade index, 3, 13, 20, 21, 26 and 45 for the nicotine content. No suitable genotype has not been identified in this group for glucose content. Genotypes within the well-suited to all environments groups are landraces of 21 and 45 for yield, 16 and 21 for quality grade, 16 for nicotine and 3,21 and 26 for glucose. In addition, genotype 26 genotype, which adapts well to bad environments with respect to the quality grade index attracted the attention (Figure 1, 2, 3, 4).

Table 3. Stability parameters for yield and quality grade index

\begin{tabular}{|c|c|c|c|c|c|c|c|c|c|c|c|c|}
\hline \multirow{2}{*}{$\mathbf{G}$} & \multicolumn{6}{|c|}{ Yield (mean: $1553.3 \mathrm{~kg} \mathrm{ha}^{-1}$ ) } & \multicolumn{6}{|c|}{ Quality Grade Index (mean: $76.73 \%$ ) } \\
\hline & $\mathbf{x}$ & $\mathbf{b}$ & $\mathbf{a}$ & $\mathbf{r}^{2}$ & CV & $S^{2} d$ & $\mathbf{x}$ & $\mathbf{b}$ & $\mathbf{a}$ & $\mathbf{r}^{2}$ & $\mathbf{C V}$ & $\mathbf{S}^{\mathbf{2}} \mathbf{d}$ \\
\hline 2 & 1608.5 & 1.10 & -10.07 & 0.88 & 5.55 & 79.66 & 78.08 & 0.71 & 23.38 & 0.76 & 8.76 & 46.85 \\
\hline 3 & 1615.3 & 1.60 & -87.43 & 0.92 & 6.23 & 101.17 & 78.58 & 0.62 & 30.68 & 0.71 & 8.52 & 44.82 \\
\hline 8 & 1543.0 & 0.51 & 74.80 & 0.90 & 6.92 & 113.91 & 67.75 & 1.17 & -22.29 & 0.98 & 3.75 & 6.46 \\
\hline 11 & 1409.9 & 1.05 & -21.52 & 0.75 & 9.16 & 166.77 & 67.33 & 1.13 & -19.31 & 0.91 & 8.99 & 36.72 \\
\hline 13 & 1495.0 & 2.19 & -192.01 & 0.93 & 8.96 & 179.60 & 73.91 & 0.94 & 2.02 & 0.90 & 6.96 & 26.46 \\
\hline 16 & 1562.5 & 1.06 & -9.11 & 0.97 & 2.55 & 15.91 & 81.50 & 1.12 & -4.84 & 0.94 & 5.74 & 21.90 \\
\hline 20 & 1471.5 & 1.02 & -12.63 & 0.73 & 9.22 & 184.01 & 77.16 & 0.71 & 22.54 & 0.96 & 3.18 & 6.01 \\
\hline 21 & 1756.7 & 1.22 & 14.10 & 0.97 & 3.54 & 38.86 & 80.08 & 0.88 & 18.65 & 0.99 & 2.91 & 5.42 \\
\hline 23 & 1513.0 & 0.21 & 118.65 & 0.90 & 1.86 & 7.91 & 74.50 & 1.51 & -41.71 & 0.96 & 7.31 & 29.67 \\
\hline 26 & 1696.7 & 1.53 & -68.12 & 0.94 & 5.05 & 73.42 & 81.58 & 0.52 & 41.54 & 0.85 & 4.51 & 13.57 \\
\hline 29 & 1371.9 & 1.07 & -29.35 & 0.88 & 6.11 & 70.23 & 78.33 & 1.26 & -18.53 & 0.96 & 5.37 & 17.69 \\
\hline 45 & 1653.3 & 1.14 & -12.13 & 0.87 & 5.64 & 87.10 & 78.75 & 1.19 & -12.39 & 0.98 & 3.66 & 8.31 \\
\hline 57 & 1395.4 & 0.86 & 5.32 & 0.82 & 6.27 & 76.55 & 77.58 & 1.33 & -24.83 & 0.94 & 7.17 & 30.94 \\
\hline St1 & 1690.8 & 0.35 & 114.85 & 0.94 & 4.56 & 59.54 & 75.25 & 1.05 & -5.67 & 0.98 & 2.87 & 4.68 \\
\hline St2 & 1515.3 & 0.67 & 46.69 & 0.98 & 6.34 & 94.43 & 80.50 & 1.91 & 10.40 & 0.97 & 3.19 & 6.59 \\
\hline CI & \pm 6.44 & \pm 0.28 & - & - & - & - & \pm 2.42 & \pm 0.20 & - & - & - & - \\
\hline
\end{tabular}

${ }^{*} \mathrm{G}$; Genotypes, $\mathrm{x}$; means, b; regression coofficient; $\mathrm{a}$; regression line intercept, $\mathrm{r}^{2}$; determination coefficient, CV; coefficient variation and $\mathrm{S}^{2} \mathrm{~d}$; deviation from regression, St; standart variety, CI; confidence interval (99\%)

The biplot graph that environments are placed on axes and environmentally oriented genotypes are scattered on axes, indicated that the first two principal components explain $85.37 \%$ of the quality grade index, $83.97 \%$ of the yield, $66.56 \%$ of the nicotine and $78.94 \%$ of the glucose (Figure 1, 2, 3, 4). The producer, who meets the seeds of next year by selecting the seeds from his own field, also controls the variation. In this respect, the data of the first two principal components revales that yield and quality grade index explain significant portion of the environmental variance. The yield and quality grade index are the two important characteristics considered for the producers in selecting the seeds, therefore, this is an expected outcome. The effects of producers' preference on variations in the characteristics of local varieties have been reported in previous studies (Atanassov et al., 2001; Zakova and Benkova, 2006; Manjunatha et al., 2007; Kurt, 2019). This significance was attributed to the population that consisting of isogenic pure lines and occurence of variation of which the significant portion is related to the environmental impact (Usturali et al., 1998; Peksuslu et al., 2002). The biplot graphic, in which environments are distributed to the axes, also enables to make different suggestions for different locations. Environments (E1-E3 and E2-E4) with the difference in year for three parameters except nicotine became closer to each other. The graphs showed that line 21 can be recommended to all environments in terms of yield. In addition, the yield performance of lines 26 and 45 will be high in Bafra and line 25 in Alaçam (Figure 1). The recommendations based on the quality grade index includes the lines 2, 21 and 26 to Bafra, and lines 16 and 29 to Alaçam (Figure 2). The village populations of different genotypes which are the consequence of natural selection, are a valuable selection material for breeders due to the improvement in their adaptability (Usturali et 
al., 1998). Because adaptation of a population to environmental changes is difficult without the variability, and therefore becomes more prone to extinction (Ahmed et al., 2014). The adaptability and stability of the cultivars to different locations are very important for the breeders to obtain the optimum yield. In addition to stability, agronomic, morphological, pathological and technological characteristics (Zencirci et al., 1990) and the initiative of the breeder (Keser et al., 1999) should be taken into account in line selection. Stability methods or multivariate statistics provide an opportunity to evaluate alone or together. All methods are aimed at identifying genotypes with desirable characteristics and stable in terms of characteristics investigated in changing environments. The results obtained for all the parameters studied and all statistical conditions discussed clearly reveals that lines 16, 21, 26 and 45 are strong tobacco candidates for the region. The registration of aforementioned lines and the use as common seeds will be effective to meet the market demands in terms of yield and quality.

Table 4. Stabilite parameters for nicotine and glucose

\begin{tabular}{rrrrrrr|rrrrrr}
\hline \multirow{6}{*}{$\mathbf{G}$} & \multicolumn{9}{c}{ Nicotine (mean: 1.53\%) } & \multicolumn{5}{c}{ Glucose (mean: 5.87\%) } \\
\cline { 2 - 12 } & $\mathbf{X}$ & $\mathbf{b}$ & $\mathbf{a}$ & $\mathbf{r}^{\mathbf{2}}$ & $\mathbf{C V}$ & $\mathbf{S} \mathbf{d}$ & $\mathbf{x}$ & $\mathbf{b}$ & $\mathbf{a}$ & $\mathbf{r}^{\mathbf{2}}$ & $\mathbf{C V}$ & $\mathbf{S}^{\mathbf{2}} \mathbf{d}$ \\
\hline $\mathbf{2}$ & 1.07 & 0.31 & 0.61 & 0.77 & 9.27 & 0.009 & 3.80 & 0.47 & 1.05 & 0.95 & 8.37 & 0.101 \\
$\mathbf{3}$ & 1.51 & 0.86 & 0.19 & 0.87 & 13.51 & 0.041 & 7.84 & 1.31 & 0.15 & 0.81 & 24.08 & 3.565 \\
$\mathbf{8}$ & 1.02 & 0.46 & 0.33 & 0.90 & 9.02 & 0.008 & 3.61 & 0.48 & 0.78 & 0.92 & 11.79 & 0.181 \\
$\mathbf{1 1}$ & 1.04 & 0.50 & 0.28 & 0.86 & 11.94 & 0.015 & 3.33 & 0.29 & 1.62 & 0.97 & 4.18 & 0.019 \\
$\mathbf{1 3}$ & 1.67 & 0.89 & 0.30 & 0.89 & 11.69 & 0.038 & 4.10 & 0.17 & 3.08 & 0.72 & 7.88 & 0.104 \\
$\mathbf{1 6}$ & 1.75 & 1.19 & -0.07 & 0.97 & 7.42 & 0.017 & 5.11 & 0.49 & 2.22 & 0.96 & 6.01 & 0.094 \\
$\mathbf{2 0}$ & 1.56 & 1.25 & -0.36 & 0.78 & 26.53 & 0.170 & 4.73 & 0.33 & 2.80 & 0.84 & 9.16 & 0.188 \\
$\mathbf{2 1}$ & 1.51 & 0.89 & 0.15 & 0.98 & 12.26 & 0.034 & 8.75 & 1.19 & 8.79 & 0.96 & 21.50 & 3.541 \\
$\mathbf{2 3}$ & 1.85 & 1.62 & -0.63 & 0.90 & 18.32 & 0.114 & 3.73 & 0.12 & 3.01 & 0.99 & 4.25 & 0.025 \\
$\mathbf{2 6}$ & 1.61 & 1.21 & -0.24 & 0.74 & 27.14 & 0.192 & 7.79 & 0.91 & 2.46 & 0.86 & 14.85 & 1.339 \\
$\mathbf{2 9}$ & 1.87 & 1.99 & -1.17 & 0.90 & 22.02 & 0.169 & 5.45 & 0.48 & 2.62 & 0.97 & 4.29 & 0.055 \\
$\mathbf{4 5}$ & 1.53 & 0.95 & 0.08 & 0.97 & 6.61 & 0.010 & 9.33 & 2.45 & -5.09 & 0.98 & 12.19 & 1.292 \\
$\mathbf{5 7}$ & 1.62 & 1.45 & -0.60 & 0.88 & 20.62 & 0.111 & 7.11 & 1.96 & -4.39 & 0.89 & 19.59 & 1.938 \\
St1 & 1.35 & 0.49 & 0.59 & 0.94 & 5.49 & 0.005 & 7.22 & 1.32 & -0.55 & 0.98 & 6.84 & 0.244 \\
St2 & 1.98 & 1.14 & 0.23 & 0.99 & 2.16 & 0.002 & 6.11 & 1.20 & -0.94 & 0.99 & 4.51 & 0.076 \\
$\mathbf{C I}$ & \pm 0.16 & \pm 0.26 & - & - & - & - & \pm 1.11 & \pm 0.38 & - & - & - \\
\hline
\end{tabular}

*G; Genotypes, $\mathrm{x}$; means, b; regression coofficient; $\mathrm{a}$; regression line intercept, $\mathrm{r}^{2}$; determination coefficient, CV; coefficient variation and $\mathrm{S}^{2} \mathrm{~d}$; deviation from regression, St; standart variety, CI; confidence interval (99\%)
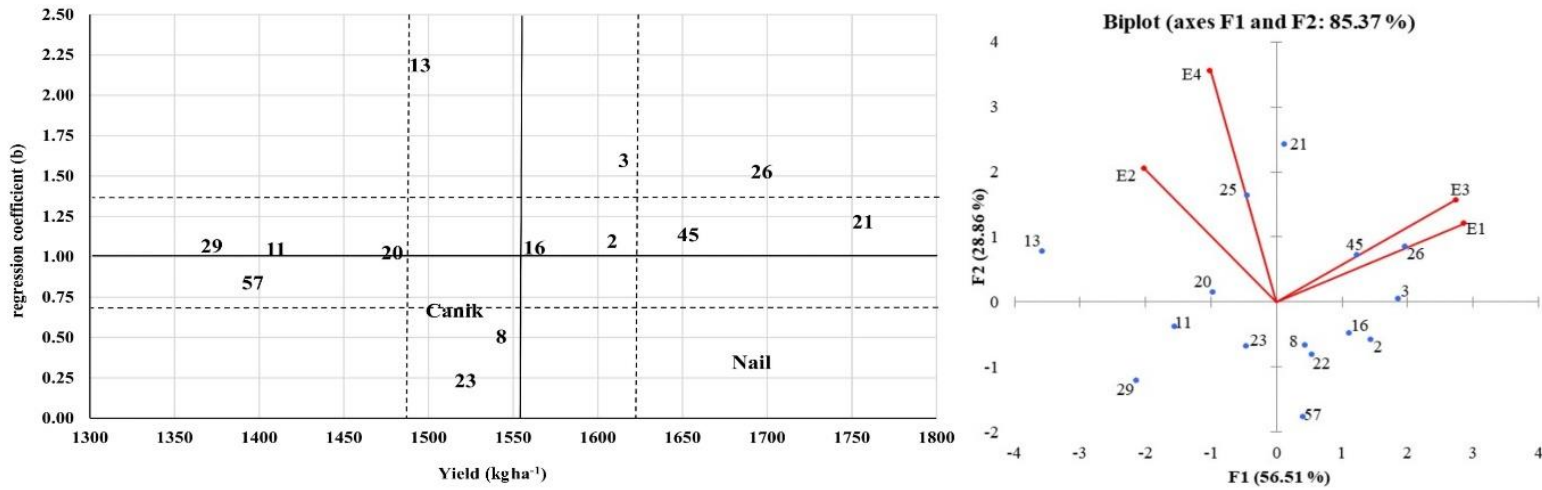

Figure 1. Stability conditions of tobacco genotypes according to yield and regression coefficients and, biplot based on environmentfocused scaling for four environments in yield parameter 

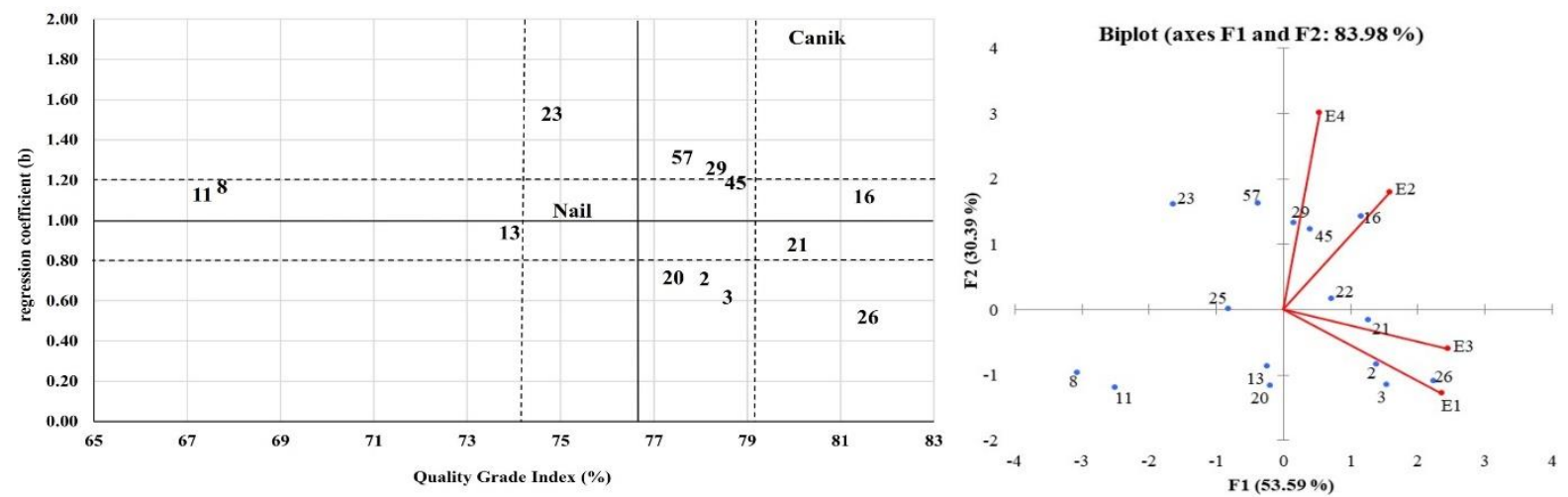

Figure 2. Stability conditions of tobacco genotypes according to quality grade index and regression coefficients and, biplot based on environment-focused scaling for four environments in quality grade index parameter
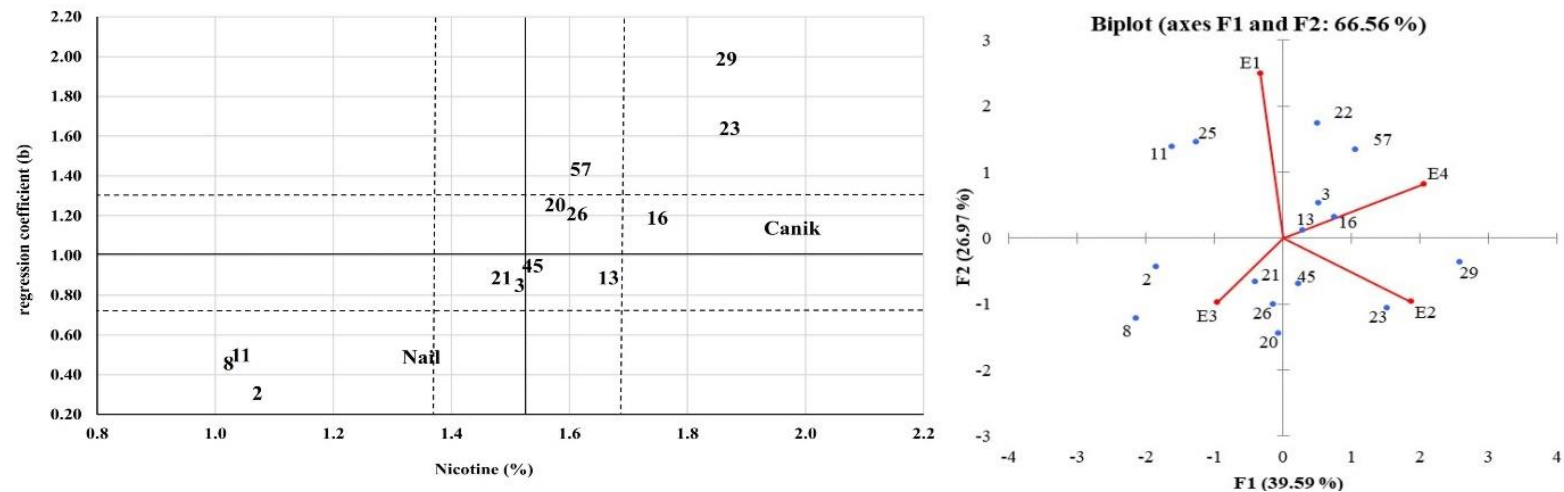

Figure 3. Stability conditions of tobacco genotypes according to nicotine and regression coefficients and, biplot based on environment-focused scaling for four environments in nicotine parameter
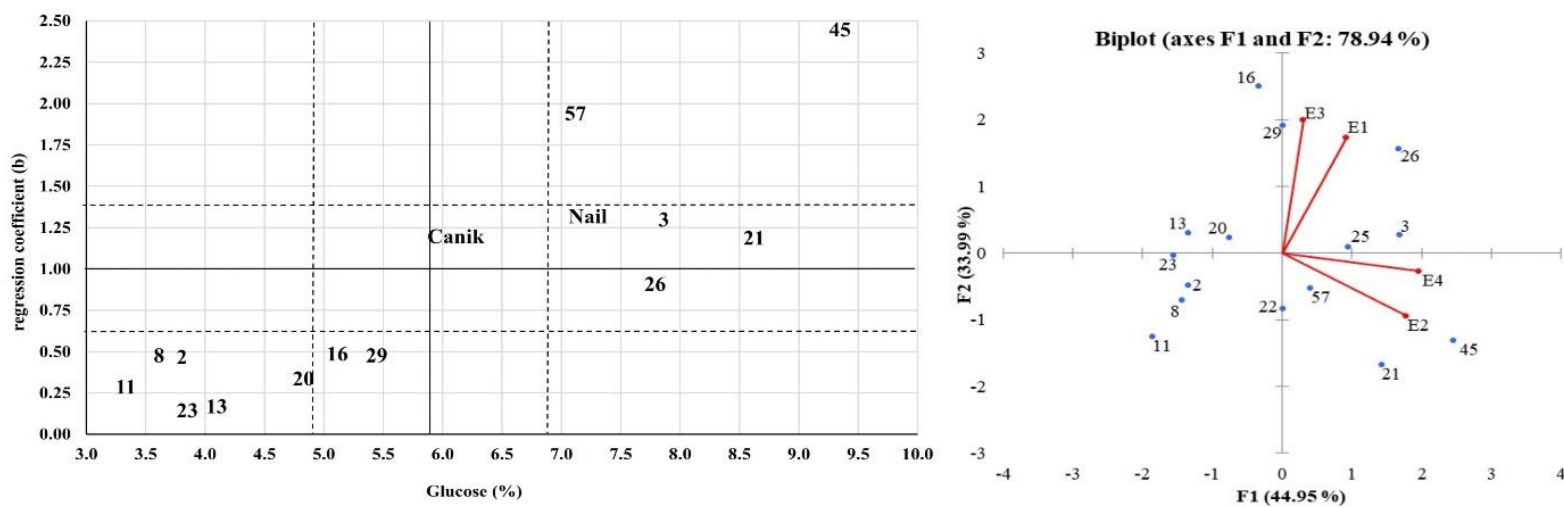

Figure 4. Stability conditions of tobacco genotypes according to glucose and regression coefficients and, biplot based on environment-focused scaling for four environments in glucose parameter

Selection breeding in tobacco is a quite rational method as based on pure line stability. In this study, agronomic and technological variations of the genotypes selected in a long term studies have been revealed and stable genotypes have been identified. Considering the market conditions, the quality values of all genotypes are within acceptable limits, and all produced a marketable product with the highest market price. Thus, genotypes with high yield and stable in yield are considered important. Genotypes of 16, 21, 26 and 45 lines meet the market demands for the cultivation regions of the Samsun type tobacco. Identifying the parents with stable and superior characteristics is one of the most important outputs of the study, which also included the characterization of regional tobaccos. These genotypes can be also reproduced and used directly as seeds.

\section{ACKNOWLEDGEMENT}

This study was supported by Socotab Leaf Tobacco Industry and Trade Incorporated Company with project named "The Project of Seed Production and Cultivars Development for Samsun Province Tobacco Production Areas". 


\section{LITERATURE CITED}

Acquaah, G. 2007. Principles of Plant Genetics and Breeding. West Sussex: Blackwell Publishing 6, 88.

Ahmed, S., F. Mohammad, Q. Ahmed and M.A.U. Khan. 2014. Assessing genetic variation for morpho-agronomic traits of some native and exotic fcv tobacco genotypes in Pakistan. American-Eurasian J. Agric. Environ. Sci. 14(5): 428-433.

Aksu, S. and G.M. Elmas. 1993. Tobacco Chemistry and Technology. Istanbul; Istanbul University Forestry Faculty Publications.

Atanassov, P., C. Borries, M. Zaharieva and P. Monneveux. 2001. Hordein polymorphism and variation of agromorphological traits in a collection of naked barley. Genet Resour Crop Evol. 48: 353-60.

Aytac, B. 2016. Determination of Nail tobacco line performance in different locations in Bafra. MSc Thesis, University of Ondokuz Mayis, Samsun, Turkey.

Bruck, H., C. Jureit, M. Hermann, A. Schulz and B. Sattelmacher. 2008. Effect of water and nitrogen supply on water use efficiency and carbon isotope discrimination in Edible Canna (Canna edulis Ker-Gawler). Plant Biology 3(4): 326-334.

Butorac, J., J. Beljo and J. Gunjaca. 2004. Study of inheritance of some agronomic and morphological traits in burley tobacco by graphic analysis of diallel cross. Plant, Soil and Environment 50(4): 162-167.

Celen, A.E., S. Ekren, V. Koparan and E. Ilker. 2016. The effects of different planting methods on tobacco quality yield and yield parameters. Proceeding of the Coresta Congress, Agronomy\&Leaf Integrity and Phytopathology\&Genetics; October 9-13; Berlin/Germany.

Crossa, J., P.N. Fox, W.H. Pfeiffer, S. Rajaram and H.G. Gauch. 1991. AMMI adjustment for statistical analysis of an international wheat yield trial. Theo. Applied Genet. 81: 2737.

Caliskan, O. 2006. Effects of different seedling production methods on yield and some quality components in tobacco (Nicotiana tabaccum L.), thyme (Origanum onites L.) and lemon balm (Melissa officinalis L.). Phd Thesis, University of Ondokuz Mayis, Samsun, Turkey.

Camas, N. 1998. The analysis of the inheritence ability of the some quantitative characters using line $\mathrm{x}$ tester method in tobacco. Phd Thesis, University of Ondokuz Mayis, Samsun, Turkey.

Camas, N., E. Esendal, S. Aytac and A.K. Ayan. 1997. Determination of the inheritance of some traits according to single sequence analysis method in breeding of hybrid variety in tobacco. Proceeding in Turkey II. Field Crops Congres; September 22-25; Samsun, Turkey. 212-216.

Camas, N., O. Caliskan, M.S. Odabas and A.K. Ayan. 2009. The effects of organic originated fertilizer doses on yield and quality of Esendal tobacco cultivar. Proceeding of the Turkey VIII. Field Crops Congress; October 19-22; Hatay, Turkey. p. 251-255.

Dehghani, H., A. Ebadi and A. Yousefi. 2006. Bioplot analysis of genotype by environment interaction for barley yield in Iran. Agron. J. 98: 388-393.

Dyulgerski, Y. and D. Dimanov. 2012. Study on heterozis behaviour related to the leaves size by the tobacco of burley variety group. Acta Agriculturae Serbica 34(17): 75-82.

Eberhart, S.A. and W.A. Russell. 1966. Stability parameters for comparing varieties. Crop Sci. 6(1): 36-40.

Ekren, S. and E. Ilker. 2017. The influence of clipping application on yield and some yield parameters of Aegean types tobaccos. Turk J Field Crops 22(2): 218-226.
Erdemci, I. 2018. Investigation of genotype $\mathrm{x}$ environment interaction in chickpea genotypes using AMMI and GGE biplot analysis. Turk J Field Crops 23(1): 20-26.

Esendal, E., A.K. Ayan, S. Aytac and N. Camas. 1997. Analysis of some characteristics of tobacco lines collected from Bafra population. Proceedings of the Turkey II. Field Crops Congress; September 22-25; Samsun, Turkey. p. 611-613.

Esendal, E., A.K. Ayan, S. Aytac and N. Camas. 2001. Analysis of some characteristics of tobacco lines collected from Bafra population. Proceedings of the Turkey IV. Field Crops Congress; September 17-21; Tekirdag, Turkey. 267-272.

Esendal, E., A.K. Ayan, S. Aytac, N. Camas and O. Caliskan. (2007). Analysis of properties of some tobacco lines from Bafra; Proceedings of the Turkey VII. Field Crops Congress; June 25-27; Erzurum, Turkey. p. 414-420.

Eser, M. 1994. A comparative study in respect of anatomy, morphology and mineral material content on the Bafra Örencik type of Nicotiana tabacum L. (Solonaceae) growing on plateau and slope area. Phd Thesis, University of Ondokuz Mayis, Samsun, Turkey.

Finlay, K.W and G.N. Wilkinson. 1963. The analysis of adaption in a plant breeding programme. Aust. Journal Agric. Res. 14(6): 742-754.

Francis, T.R and L.W. Kannenberg. 1978. Yield stability studies in short season maize. i: a descriptive method for grouping genotypes. Can. J. Plant Sci. 58(4): 1029-1034.

Gauch, H.G. 1988. Model selection and validation for yield trials with interaction. Biometr. 44(3): 705-715.

Gauch, H.G. 1992. Statistical analysis of regional yield trials: AMMI analysis of factorial designs. Amsterdam: Elsevier.

Karpat, H. 1989. Studies on taxonomic characteristics of Samsun-Bafra tobacco (Nicotiana tabacum L.) cultivars. Phd Thesis, University of Ondokuz Mayis, Samsun, Turkey.

Keser, M., N. Bolat, F. Altay, M.T. Cetinel, N. Colak and A.L. Sever. 1999. Use of some stability parameters in variety development studies. Cereals symposium, June 8-11, pp. 6469, Konya, Turkey.

Kinay, A. 2014. Yield and quality properties in some oriental tobacco (Nicotiana tabacum L.) hybrids. Phd Thesis, University of Tokat Gaziosmanpasa, Samsun, Turkey.

Kinay, A. 2018. Effects of cadmium on nicotine, reducing sugar and phenolic contents of Basma tobacco variety. Fresenius Environmetal Bulletin 27(12A): 9195-9202.

Korubin-Aleksoska, A., J. Miceska and G. Aleksoski. 2014. Plant breeding for creation of late-maturing oriental tobacco genotypes. Тутун/Tobacco 64(1-6): 5-11.

Kurt, D. 2019. Genotype x environment interactions of Basma type tobacco (Nicotiana tabacum L.) lines selected for superior characteristics. Phd Thesis, University of Ondokuz Mayis, Samsun, Turkey.

Leffingwell, J.C. 2001. Chemical constituents of tobacco leaf and differences among tobacco types. http://www.leffingwell.com/download/tobacco_chemistry.pd f. (Access Dec. 5 2019).

Manjunatha, T., IS. Bisht, K.V. Bhat and B.P. Singh. 2007. Genetic diversity in barley (Hordeum vulgare L. ssp. vulgare) landraces from Uttaranchal Himalaya of India. Genet. Resour. Crop Ev. 54: 55-65.

Mohammadi, M., R. Karimizadeh, N. Sabaghnia and M.K. Shefazadeh. 2012. Genotype x environment interaction and yield stablity analysis of new improved bread what genotypes. Turk J Field Crops 17(1): 67-73.

Mumtaz, A., D. Hussain, M. Saeed, M. Arshad and M.I. Yousaf. 2019. Stability and adaptability of sorghum hybrids elucidated with genotype-environment interaction biplots. Turk J Field Crops 24(2): 155-163. 
Odabasoglu, M. 1994. Tobacco Chemistry. Samsun: Ondokuz Mayss University Science Faculty Publications.

Peksuslu, A., C.O. Sabanci, R. Kucukozden and S. Sekin. 2002. Genotype $\mathrm{x}$ environment interactions and heritabilities of some important agronomic traits in tobacco. Proceeding of the II. Balkan Scientific Conference Quality and Efficiency of the Tobacco Production, Treatment and Processing; September; Plovdiv, Bulgaria.

Peksuslu, A., I. Yilmaz, A. Inal and H. Kartal. 2012. Tobacco Genotypes of Turkey. Journal of Aegean Agricultural Research Institute, Anadolu 22(2): 82-90.

Ramusino, M.C., B.S. Dattilo, A. Lucibello and S.G. Rossi. 1994. Determination of 25 low molecular weight carbohydrates in tobacco by high performance ion chromatography. Beiträge zur Tabakforschung International/Contributions to Tobacco Research 16(2): 7784.

Roemer, E., M.K. Schorp, J.J. Piadé, J.I. Seeman, D.E. Leyden and H.J. Haussmann. 2012. Scientific assessment of the use of sugars as cigarette tobacco ingredients: a review of published and other publicly available studies. Critical Reviews Toxicology 42(3): 244-278.

Romagosa, I and P.N. Fox. 1993. Genotype x environment interaction and adaptation. London: Hayward, M.D., Bosemark, N.O., Romagosa, I. (Eds.). Plant Breeding: Principles and Prospects; p. 373-390.

Sabanci, C.O. 1997. Methods used in stability analysis and stability parameters. Journal of Aegean Agricultural Research Institute, Anadolu 7(1): 75-90.

Sadeghi, S.M., H. Samizadeh, E. Amiri and M. Ashouri. 2011. Additive main effects and multiplicative interactions (ammi) analysis of dry leaf yield in tobacco hybrids across environments. African Journal of Biotechnology 10(21): 4358-4364.

Sayar, M.S., A.E. Anlarsal and M. Basbag. 2013. Genotypeenvironment interactions and stability analysis for dry-matter yield and seed yield in hungarian vetch (Vicia pannonica Crantz.). Turk J Field Crops 18(2): 238-246.

Sekin, S. 1979. Researches on some analysis methods in tobacco: chemical composition of Aegean tobacco and changes during fermentation. Associate professor thesis. Ege University, Izmir, Turkey.

Senbayram, M., S. Ekren and S. Sekin. 2005. Effects of ecological conditions and nutrients on oriental tobacco quality. Proceeding of the Workshop on Tobacco Farming and Problems in the Aegean Region; December 21; Izmir, Turkey.

Teich, A.H. 1983. Genotype-environment interaction variances in yield of winter wheat. Cereal Research Communication. 11(1): 15-20.

Topal, M and N. Yildiz. 2011. Examination of relationship among parametric and nonparametric stability estimation methods used in determintion of genotype $\times$ environment interaction. Anadolu J Agr Sci. 26(1): 10-23.

Usturali, A., R. Apti, H. Otan, G. Yazan and H. Sengul. 1998. Selection studies on Sarıbağlar subpopulation in the Aegean tobacco region. Journal of Aegean Agricultural Research Institute, Anadolu 8(1): 1-15.

Westcoff, B. 1987. A method of assessing the yield stability of crops. J. Agric. Sci. 108(2): 267-274.

Wu, Z., W.W. Weeks and R.C. Long. 1992. Contribution of neutral volatiles to flavor intensity of tobacco during smoking. J. Agric. Food. Chem. 40(10): 1917-1921.

Xia, B., M. Feng, G. Xu, J. Xu, S. Li, X. Chen, L. Ding and Y. Zhou. 2014. Investigation of the chemical compositions in tobacco of different origins and maturities at harvest by GCMS and HPLC-PDA-QTOF-MS. Journal of Agricultural and Food Chemistry 62: 4979-4987.

Yan, W., P.L. Cornelius, J. Crossa and L.A. Hunt. 2001. Two types of GGE biplots for analyzing multi-environment trial data. Crop Sci. 41(3): 656-663.

Yazan, G. and A.S. Gencer. 2001. Determination of polyphenol compounds in Aegean region tobacco and investigation of their effects on smoke condensate. Proceedings of the Turkey IV. Field Crops Congress; September 17-21; Tekirdag, Turkey.

Zakova, M. and M. Benkova. 2006. Characterization of spring barley accessions based on multivariate analysis. Commun. Biom. Crop Sci. 1(2): 124-34.

Zeba, N. and M. Isbat. 2011. Multivariate analysis for yield and yield contributing traits in $\mathrm{F} 0$ and $\mathrm{F} 1$ generations in tobacco. Journal of Experimental Bioscience 2(1): 101-106.

Zencirci, N., V. Eser and I. Baran. 1990. An approach to comparison of some stability statistics. Ankara: Field Crops Central Research Institue Publications.

Zorba, T. 2008. A study on determination of tobacco cultivars and lines, best suited for Black Sea region and their expertise data. MSc Thesis, University of Ondokuz Mayıs, Samsun, Turkey. 